\title{
A molecular switch between the outer and the inner vestibules of the voltage-gated $\mathrm{Na}^{+}$channel
}

\author{
René Cervenka, Péter Lukács, Touran Zarrabi, Xaver Koenig, Agnés Mike, Karlheinz Hilber, Hannes Todt \\ From 16th Scientific Symposium of the Austrian Pharmacological Society (APHAR) \\ Vienna, Austria. 25-27 November 2010
}

\section{Background}

Voltage-gated ion channels are transmembrane proteins that undergo complex conformational changes during their gating transitions. Both functional and structural data from $\mathrm{K}^{+}$channels suggest that extracellular and intracellular parts of the pore communicate with each other via a trajectory of interacting amino acids. No crystal structures are available for voltage-gated $\mathrm{Na}^{+}$channels but functional data suggest a similar intramolecular communication involving the inner and outer vestibules. However, the mechanism of such communication is unknown. Here, we report that amino acid I1575 in the middle of transmembrane segment 6 of domain IV (DIV-S6) in the $\mathrm{rNa}_{\mathrm{V}} 1.4$ channel may act as molecular switch allowing for interaction between outer and inner vestibule.

\section{Methods and results}

Cysteine scanning mutagenesis of the internal part of DIV-S6 revealed that only mutations at site 1575 rescued the channel from a unique kinetic state ("ultraslow inactivation", $\mathrm{I}_{\mathrm{US}}$ ) produced by the mutation K1237E in the selectivity filter. The fact that mutations at site 1575 modulate $\mathrm{I}_{\mathrm{US}}$ produced by K1237E strongly suggests an interaction between these sites. To elucidate how $\mathrm{I}_{\mathrm{US}}$ is generated, we "forced" large organic cations through the channel, which resulted in a significant linear correlation between the increase in the amplitude of recovery from $I_{U S}$ and the diameter of the permeating cations. Additionally, we show that a permeation pathway for the permanently charged lidocaine analogue QX222, opened by mutations at site 1575 , is closed by the addition of K1237E to these I1575 mutants.

\footnotetext{
* Correspondence: hannes.todt@meduniwien.ac.at Institute of Pharmacology, Center of Physiology and Pharmacology, Medical University of Vienna, 1090 Vienna, Austria
}

\section{Conclusions}

These results support the notion that an increase in the size of the selectivity filter produced by the mutation K1237E gives rise to an interaction of E1237 with I1575 of the adjacent S6 segment thereby generating IUS.

\section{Acknowledgements}

This work was supported by grants P21006-B11, P17509-B11, P13961-B05 from the FWF.

Published: 16 November 2010

doi:10.1186/1471-2210-10-S1-A23

Cite this article as: Cervenka et al: A molecular switch between the outer and the inner vestibules of the voltage-gated $\mathrm{Na}^{+}$channel. $B M C$ Pharmacology 2010 10(Suppl 1):A23.
Submit your next manuscript to BioMed Central and take full advantage of:

- Convenient online submission

- Thorough peer review

- No space constraints or color figure charges

- Immediate publication on acceptance

- Inclusion in PubMed, CAS, Scopus and Google Scholar

- Research which is freely available for redistribution
() Biomed Central 